\title{
Parathyroid Development and the Role of Tubulin Chaperone $E$
}

\author{
Ruti Parvaria George A. Diaz $^{\text {b Eli Hershkovitz }}{ }^{c}$ \\ a Department of Developmental Genetics and Virology, Faculty of Health Sciences and National Institute for \\ Biotechnology, Ben Gurion University of the Negev, Beer Sheva, Israel; ${ }^{b}$ Departments of Human Genetics and \\ Pediatrics, Mount Sinai School of Medicine, New York, N.Y., USA, and 'Pediatric Endocrinology \& Metabolic Unit, \\ Soroka Medical University Center, Beer Sheva, Israel
}

\section{Key Words}

Parathyroid glands development - Hypoparathyroidism • HRD syndrome $\cdot$ Tubulin chaperone $\mathrm{E}$

\begin{abstract}
The development of the parathyroid glands involves complex embryonic processes of cell-specific differentiation and migration of the glands from their sites of origin in the pharynx and pharyngeal pouches to their final positions along the ventral midline of the pharyngeal and upper thoracic region. The recognition of several distinct genetic forms of isolated and syndromic hypoparathyroidism led us to review the recent findings on the molecular mechanisms of the development of the parathyroid glands. Although far from being understood, a special emphasis was given to the possible role of tubulin chaperone $E$ (TBCE), which was implicated in the pathogenesis of the hypopathyroidism, retardation and dysmorphism (HRD) syndrome. The novel finding that TBCE plays a critical role in the formation of the parathyroid opens a novel domain of research, not anticipated previous$l y$, into the complex process of parathyroid development.
\end{abstract}

Copyright $\odot 2007$ S. Karger AG, Basel

\section{Introduction}

The principal function of the parathyroid glands is to regulate calcium ion concentration by release of parathyroid hormone (PTH).

\section{KARGER}

Fax +41613061234 E-Mail karger@karger.ch www.karger.com
(C) 2007 S. Karger AG, Basel

0301-0163/07/0671-0012\$23.50/0

Accessible online at:

www.karger.com/hre
The parathyroid glands develop in humans between 5 and 12 weeks of gestation from the 3rd and 4th pharyngeal pouches. The epithelium of the dorsal part of the $3 \mathrm{rd}$ and 4 th pouches proliferates during the 5th week and forms small nodules on the dorsal aspect of each pouch. Vascular mesenchyme soon grows into these nodules, forming a capillary network. The principal cells differentiate during the embryonic period and are believed to become functionally active in regulating fetal calcium metabolism. The epithelium of the dorsal wing of the third pouch differentiates into the inferior parathyroid gland while the ventral wing forms the thymus, then the gland primordia disconnect from the pharyngeal wall and migrate in a caudal and medial direction and become closely associated with the inferior region of the thyroid gland. The parathyroids can become embedded within the thyroid, but always remain a separate organ. The superior parathyroid glands are derived by the 6 th week from the dorsal part of the 4th pharyngeal pouches and lie on the dorsal surface of the thyroid gland. The superior glands are more constant in position than the inferior ones. Occasionally an inferior gland fails to descend and remains near the bifurcation of the common carotid artery. In other cases it may accompany the thymus into the thorax. Uncommonly there are more than four parathyroid glands. Supernumerary parathyroid glands probably result from division of the primordia of the original glands. Absence of a parathyroid gland results from failure of one of the primordia to differentiate or from atrophy of a gland early in development [1].

Tel. +972 8647 9967, Fax +972 8627 6215, E-Mail ruthi@bgu.ac.il 
Table 1. Genetic disorders associated with congenital hypoparathyroidism

\begin{tabular}{|c|c|c|c|c|c|}
\hline Gene & $\begin{array}{l}\text { Chromosomal } \\
\text { location }\end{array}$ & Disease & Inheritance & Main clinical features & $\begin{array}{l}\text { OMIM } \\
\text { (No.) }\end{array}$ \\
\hline PTH & $11 \mathrm{p} 15$ & hypoРTH & $\mathrm{AR} / \mathrm{AD}$ & isolated hypoPTH & $\begin{array}{l}146200 \\
168450\end{array}$ \\
\hline GCMB & $6 \mathrm{p} 23-\mathrm{p} 24$ & hypoРTH & AR & isolated hypoPTH & $\begin{array}{l}146200 \\
603716\end{array}$ \\
\hline CaSR & $3 q 13$ & $\begin{array}{l}\text { hypocalcemia } \\
\text { with hypercalciuria }\end{array}$ & $\mathrm{AD}$ & $\begin{array}{l}\text { low or inappropriate } \\
\text { 'normal' PTH levels }\end{array}$ & $\begin{array}{l}146200 \\
601199\end{array}$ \\
\hline $\begin{array}{l}\text { Regulatory } \\
\text { elements of SOX3 }\end{array}$ & $\mathrm{Xq} 26-27$ & hypoРTH & $\begin{array}{l}\text { X-linked } \\
\text { recessive }\end{array}$ & isolated hypoPTH & 307700 \\
\hline $\begin{array}{l}\text { TBX1, CrkL and } \\
\text { others }\end{array}$ & $\begin{array}{l}22 \mathrm{q} 11.2 \\
10 \mathrm{p} 13\end{array}$ & DiGeorge syndrome & $\begin{array}{l}\text { AD or } \\
\text { sporadic }\end{array}$ & $\begin{array}{l}\text { hypoPTH, thymic hypoplasia } \\
\text { outflow tract defects of the heart } \\
\text { facial dysmorphism }\end{array}$ & $\begin{array}{l}188400 \\
601362\end{array}$ \\
\hline GATA 3 & 10 p15 & HDR syndrome & $\mathrm{AD}$ & hypoPTH, deafness, renal failure & 146255 \\
\hline TBCE & $1 q 42-43$ & HRD syndrome & $\mathrm{AR}$ & $\begin{array}{l}\text { hypoPTH, growth and developmental } \\
\text { retardation dysmorphism }\end{array}$ & 241410 \\
\hline Unknown & Unknown & $\begin{array}{l}\text { hypoparathyroidism- } \\
\text { lymph edema syndrome }\end{array}$ & $\begin{array}{l}\text { AR or X-linked } \\
\text { recessive }\end{array}$ & renal failure & 247410 \\
\hline
\end{tabular}

$\mathrm{AR}=$ Autosomal recessive, $\mathrm{AD}=$ autosomal dominant.

\section{Molecular Mechanisms Determining Parathyroid Glands Development}

Extensive research, mainly in murine models, has identified secreted molecules and transcription factors important in the formation of the parathyroid glands. Mice have only two parathyroid glands that are generated exclusively from the third pharyngeal pouch and are morphologically distinct by embryonic (E) day 8 , fully developed by E12, and in their final position by E15.5 [ 2 and references therein]. The molecular mechanisms defined in mice have proven to be relevant to human parathyroid development as well and defects in these pathways were found to play a role in various forms of congenital hypoparathyroidism (table 1). A summary of the molecules predicted to have a role in parathyroid development and their presumed regulators is presented in table 2.

Signals from pharyngeal endoderm, that gives rise to the thyroid, parathyroid and thymus glands, pattern the neural crest arch and mesoderm [3-7]. Ablation of the cranial neural crest in the chick results in aplasia or dysplasia of the thymus, parathyroid and thyroid and the heart [8]. The neural crest mesenchyme contributes connective tissue elements to the thymus and parathyroid
[9-11]. However, the precise role of neural crest cells in the development of organs derived from the pharyngeal region remains unclear.

\section{Secreted Signaling Regulators}

Retinoid Signaling. Retinoid signaling has been shown to be essential for the formation of the 3rd and 4th pharyngeal arches $[12,13]$. Mice deficient in retinoic acid (RA) due to targeted inactivation of retinaldehyde dehydrogenase 2, the enzyme responsible for early embryonic RA synthesis, die in utero because of cardiac malformations. Transient maternal RA supplementation from E7.5 rescues these embryos, but they exhibit impaired development of the 3rd-6th branchial arch region [14]. RA is known to induce the expression of the family of Hox genes transcription factor (see below) in sequential order corresponding to their chromosome location according to the time and level of RA [15]. Expression of Hoxb1 and Hoxa1 were indeed demonstrated to be markedly reduced, but the expression of Hoxa3 was not verified. The secreted factor Fgf8 is expressed at abnormally low levels in the RA mutants [14] suggesting this growth factor as a downstream 
Table 2. Genes suggested being involved in the development of the murine parathyroid glands

\begin{tabular}{|c|c|c|c|}
\hline Gene & Function & Downstream of & Upstream of \\
\hline Retinoic acid & secreted signaling protein & & Hox genes, Fgf8 \\
\hline Shh & secreted signaling protein & & Fgf8, Bmp4 \\
\hline Fgf8 & secreted signaling protein & retinoic acid, Shh, Tbx1, Crkl & Crkl \\
\hline Bmp4 & secreted signaling protein & Shh & \\
\hline TGF $\beta$ & secreted signaling protein & & Tbx1, Crkl \\
\hline Vegf & secreted signaling protein & Tbx1, Crkl & Tbx1, Crkl \\
\hline Crkl & $\begin{array}{l}\text { adaptor protein, tyrosine } \\
\text { kinase signaling }\end{array}$ & TGF $\beta$, Fgf8 & \\
\hline Hoxa 3 & transcription factor & RETINOIC acid (?) & Pax1, Gcm2, Eya1 \\
\hline $\operatorname{Pax} 9$ & transcription factor & Tbx1 & Eya1 \\
\hline Paxl & transcription factor & Hoxa 3 & Gcm2, Eya1 \\
\hline GCM2 & transcription factor & Hoxa 3, Pax1, Pax9, Eya1, Six1, Tbx1 & \\
\hline Eyal & transcription factor & Hoxa 3, Pax1, Pax9 & Six1, Gcm2 \\
\hline Six1 & transcription factor & Eya1 & \\
\hline Sox3 & transcription factor & & \\
\hline Tbxl & transcription factor & & Pax9, Gcm2 \\
\hline GATA3 & transcription factor & TGF $\beta$, Vegf & \\
\hline
\end{tabular}

target of RA signaling. The transcription factor Tbx1 expression is not affected in the mutant, thus it is not considered to be a critical determinant of the phenotype [14].

Shh, Fgf8 and Bmp4. These secreted signaling molecules produced by the pharyngeal endoderm and ectoderm have been demonstrated to have a role in the development of the parathyroid glands [16 and references therein]. Multiple cell populations of the pharyngeal arches require Shh activity for survival, but not for initial formation and patterning. Shh appears to act predominantly as a repressor of the key pharyngeal pouch identity genes Fgf8 and Bmp4 since the parathyroid glands are missing in Shh-/- mice while the thymus domain and the population of Bmp4 expressing cells are expanded [16]. Shh and the transcription factor Hoxa3 (see below) appear to be in different pathways since their expression patterns are not affected in the reciprocal null mice [16].

$T G F \beta$. Specific inactivation of TGF $\beta$ signaling in neural crest stem cells by conditional inactivation of the TGF $\beta$ receptor type II gene (T $\beta R I I)$ in mice causes the characteristic cardiovascular defects and the thymic, parathyroid and craniofacial anomalies of the DiGeorge syndrome (DGS) [17]. Tbxl and Crkl mutants, two genes encoded in the $3-\mathrm{Mb}$ common deletion of $22 \mathrm{q} 11$ causing the DGS, are also implicated in neural crest cell migration. Knockout of each of these gene phenocopies DGS and interferes with neural crest migration into the pharyngeal arch complex $[18,19]$ and the actions of Fgf8 and Vegf [18]. CrkL is an adaptor protein that is highly ex- pressed in neural crest during mouse development and which may mediate TGF $\beta$ and Fgf8 signaling. $40 \%$ of $\mathrm{Crkl}^{-/-}$embryos had abnormalities in the development of the thymus, thyroid and parathyroid glands [20]. Phosphorylation of Crkl is detectable at E10 and restricted to a narrow time window as it is no longer observed from E11.5 onward. This phosphorylation is impaired in TßRII-deficient neural crest cells [17]. Fgf8 induces tyrosine phosphorylation of FgfRs 1 and 2 and their binding to Crkl [20]. Moreover, Crkl is required for normal cellular responses to Fgf8, including survival and migration, Erk activation, and target gene expression [20]. Crkl functions in additional signaling pathways activated by VEGF, EGF, PDGF and BMP/TGF $\beta$ [20 and references therein]. A potential association between TGF $\beta$, Src and CrkL signaling was suggested since TGF $\beta$ signaling has been reported to induce phosphorylation and activation of Src tyrosine kinase regulating TGF $\beta$-dependent apoptosis, cell migration or tumor cell invasiveness [17].

Mice that are compound heterozygotes for null alleles of CRKL and the transcription factor TBX1 (see below), display a striking increase in the penetrance and expressivity of a DGS-like phenotype compared to heterozygosity at either locus alone. Furthermore, these two genes have critical dose-dependent functions in pharyngeal segmentation, patterning of the pharyngeal apparatus along the anteroposterior axis, and local regulation of RA metabolism and signaling [21]. However the mechanisms mediating this synergy are not known. 


\section{The Role of Transcription Factors}

Several transcription factor genes have been implicated in the development of the pharyngeal organs.

Hoxa3. This member of the Hox gene family, which specifies positional identity in the developing embryo [15], is strongly expressed in the 3rd pharyngeal arch and pouch from which the two parathyroid glands of mice develop, and in the 4th pharyngeal pouch endoderm and neural crest mesenchyme [22]. Inactivation of the Hoxa3 gene in mice results in parathyroid and thymic aplasia and persistent ultimobranchial bodies [22-24].

Pax1 and Pax9. These are closely related members of the paired-box gene family, which play critical roles in the development of multiple organs [25-28]. Inactivation of Pax9 results in early failure of thymus, parathyroid and ultimobranchial body formation [29], while Paxl mutants have hypoplastic parathyroid and thymus and disturbed thymocyte maturation $[30,31]$. The initiation of pax-1 expression in the 3rd pouch is not disturbed in Hoxa3 null mice. However, by E10.5, Hoxa 3 homozygotes show a marked reduction in the level of pax-1 expression in the 3rd pouch and by E11, pax-1 expression is not detectable in the 3 rd pouch of the mutant. This observation suggests that pax-1 is downstream of Hoxa3 [22].

$G C M B$. The human and murine ( $\mathrm{Gcm} 2)$ homologs of the Drosophila glial cells missing gene play a key role in the organogenesis of the parathyroid gland [32-34]. GCMB is exclusively expressed in the PTH-secreting cells of the developing and mature parathyroid gland [33]. During parathyroid organogenesis, Hoxa3 is required for the initiation of $\mathrm{Gcm} 2$ expression in the 3rd pouch endoderm, and both Hoxa3 and Paxl are required for the maintenance of $\mathrm{Gcm} 2$ expression [31]. Gcm 2 null mice lacked parathyroid glands and exhibited biological hypoparathyroidism [35]. However, these mice were viable and fertile and had only a mildly abnormal bone phenotype. Despite their lack of parathyroid glands, Gcm2-deficient mice had PTH serum levels identical to those of wildtype mice, as did parathyroidectomized wild-type animals. Thus, mice appear to have an auxiliary mechanism for the regulation of calcium homeostasis, suggested to be a downregulatable production of PTH from the thymus [35].

In contrast to $\mathrm{Gcm} 2$ null mice, a homozygous deletion of the 5'-end of the GCMB gene was described in a 9month-old girl with parathyroid agenesis accompanied by hypoparathyroidism characterized by hypocalcemia, hyperphosphatemia, and absent or very low circulating PTH levels [36]. This discrepancy might indicate that the thymus plays a less important role as an auxiliary source of PTH in humans than in mice. Loss of the GCMB gene appears to cause a highly specific embryological defect that is limited to parathyroid cells, thus confirming its restricted role in the control of differentiation of cells into parathyroid glands. The correlation between GCMB expression and differentiation into parathyroid cells is exemplified by the upregulation of GCMB expression in abnormal parathyroid glands of hyperparathyroidism and the decreases in expression in response to hypocalcemia [37].

Eyes Absent 1 (Eya1). Eya genes regulate organogenesis in both vertebrates and invertebrates. Targeted inactivation of murine Eyal impairs early developmental processes in multiple organs including ear, kidney, thymus parathyroid and thyroid [38]. Eyal is expressed in all three cell types of the 3rd pharyngeal clefts: neural crestderived arch mesenchyme, pouch endoderm and possibly the surface ectoderm, during thymic and parathyroid development from E9.5. The organ primordia for both of these structures failed to form in Eya-/- embryos [39]. Expression of the transcription factor Sixl is markedly reduced in all 3rd pharyngeal cleft derivatives in Eya-/embryos, indicating that its transcription is Eyal-dependent. In addition, $\mathrm{Gcm} 2$ expression is undetectable at E10.5, but the expression of Hox and Pax9 and Pax 1 genes is preserved at E9.5-10.5 [39]. This expression pattern fits with the finding that Eyal functions in an evolutionarily conserved cassette downstream of Pax genes and upstream of Six genes during the development of pharyngeal pouch endoderm. There are no significant changes of Eya1 expression in the pharyngeal pouch endoderm at E9.5 of Pax9 null embryos [39]. Similarly, $\mathrm{Gcm} 2$ expression is initiated normally at E9.5-10.5 in Pax1 single mutants [31]. As this finding contradicts the theory of Eyal functioning downstream of the Pax genes, the possibility has been suggested that Paxl and Pax9 function redundantly in the pharyngeal pouches and that a critical threshold of Pax1/Pax9 protein expression in pharyngeal endoderm regulates Eyal expression. Such compensatory upregulation has been noted for Pax1 and Pax9 in the formation of other organs [40]. However, Paxl apparently does not compensate for Pax 9 deficiency during embryonic parathyroid and thymus formation. Thus, it was suggested that $\mathrm{Gcm} 2$ expression is regulated by the Hoxa3-Pax1/9-Eya1 pathway during parathyroid organogenesis [31].

Sox3. Sox 3 is a transcription factor belonging to a family of high mobility group box proteins that includes SRY, the Y-linked sex determining gene and other master reg- 
ulator genes [reviewed in 41]. It was recently implicated to have a role in the development of the parathyroid glands by the finding that the X-linked recessive form of hypoparathyroidism is caused by an interstitial deletioninsertion involving chromosomes 2p25.3 and Xq27.1 near the Sox 3 gene [42]. The deletion of $23-25 \mathrm{~kb}$ telomeric to Sox 3 was postulated to ablate transcriptional regulatory regions. The demonstration that Sox 3 is transcribed between 10.5 and $15.5 \mathrm{dpc}$ in the pharyngeal pouches and developing parathyroids of the mouse embryo supports this hypothesis. Mutations causing altered transcription levels of SOX3 do not result in parathyroid abnormalities but in hypopituitarism and a mutation in the SOX 3 coding region causes hypopituitarism, mental retardation and growth hormone deficiency. Sox3-null mice have abnormal pituitary development, craniofacial abnormalities and midline central nervous system (CNS) defects, but no parathyroid abnormality has been reported $[42$ and references therein]. These observations support the hypothesis that the X-linked form of hypoparathyroidism is caused by disruption of regulatory elements of Sox3.

Tbx1. The role of the genes present in the deletion causing the DGS has been extensively studied [18]. The deletion mutants Df1 or Lgdel, which reduce the 22 genes of the deletion to hemizygosity [43], recapitulate the DGS phenotype. The embryological phenotype of the transcription factor Tbx1+/- mice is indistinguishable from the Df1 mutants [44-46], and thus haploinsufficiency of Tbx1 is proposed to be the major contributor to the syndrome. Microarray analysis of mice lacking Tbx1 [47] identified additional transcription factors (Pax9, Gcm2 and $\mathrm{Gbx} 2$ ) that are quantitatively reduced in expression, thus suggesting that they are Tbx1 target genes.

GATA3. The syndrome of hypoparathyroidism, deafness and renal anomalies (HDR) was found to be caused by mutations causing loss of function in the GATA3 transcription factor, consistent with the expression pattern of GATA3 during human and mouse embryogenesis [48]. GATA3 is also expressed in the developing CNS and the hematopoietic organs in human and mice, and accordingly, homozygous Gata3 knockout mice have defects of the CNS and T-cell development, but not hypoparathyroidism [49]. The manner in which GATA3 mutations cause the syndrome remains to be elucidated since direct correlation between the phenotypic presentation and the mutations could not be established [50].

\section{Tubulin Chaperone E (TBCE) and Parathyroid Development}

The syndrome of hypoparathyroidism, growth and mental retardation, and characteristic dysmorphism (HRD syndrome) known alternatively as autosomal recessive Kenny-Caffey syndrome [51] (MIM244460), HRD [52] (MIM241410), or Sanjad-Sakati syndrome [53] is caused by mutations in the tubulin-specific chaperone E gene, TBCE (fig. 1) [54]. The cardinal manifestations of this disease include parathyroid aplasia, growth failure, ocular malformations and microcephalic mental retardation (fig. 2). Secondary features include characteristic facial dysmorphism, cryptorchidism/micropenis, susceptibility to bacterial infection and variable osteosclerosis [55]. The hypoparathyroidism is due to the absence of the parathyroid glands [Hershkovitz, unpubl. data, and 56].

Coincident with this discovery, a missense mutation in murine Tbce (W527G) was described in a mouse model of peripheral motor neuropathy, pmn $[57,58]$. The W527G mutation destabilized the chaperone, resulting in diminished protein levels [56]. The original pmn mice had low birth weight, decreased brain size, and hypogonadism, reminiscent of the human trait, but no hypoparathyroidism was noted [59]. As HRD patients have survived to late adolescence, some have developed a hypoventilation syndrome and lower motor neuropathy [N. Sakati, pers. commun.], presumably secondary to a neurodegenerative process similar to that described in pmn mice. Since mice that lack the parathyroid glands have PTH serum levels identical to those of wild-type mice, as do parathyroidectomized wild-type animals, are viable and fertile and have only a mildly abnormal bone phenotype [35], it is possible that the parathyroid defect in pmn mice had been overlooked. Thus, the concordance between the human and murine phenotypes is greater than previously appreciated.

Presently, the only known function for TBCE is a chaperone of $\alpha$-tubulin.

\section{Tubulin Folding and Assembly}

Microtubules are polymerized from $\alpha / \beta$-tubulin heterodimers [60]. Newly synthesized $\alpha$ - and $\beta$-tubulin polypeptides undergo a sequence of folding steps catalyzed by chaperones. Initially, the tubulins are associated with the hexameric prefoldin complex that passes them on to the cytosolic chaperonin complex [61], and they are then further processed by tubulin-folding cofactors [62, 


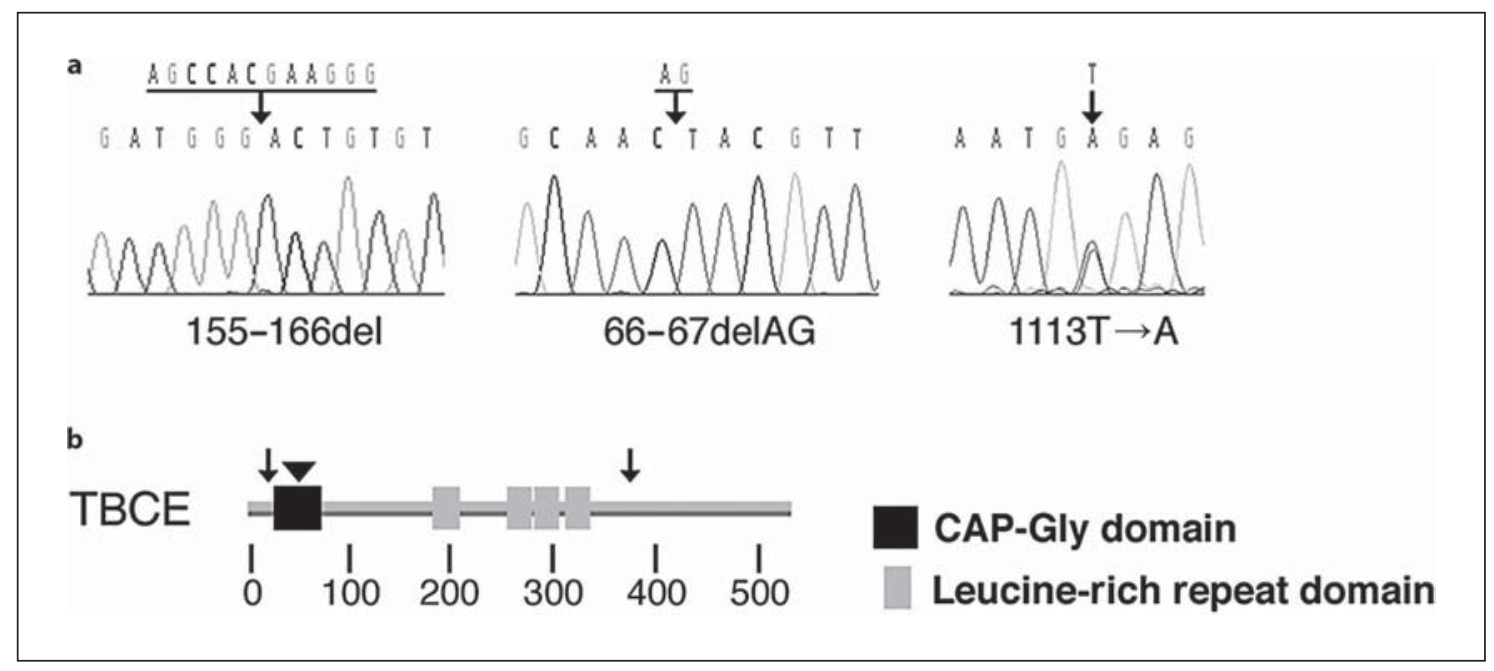

Fig. 1. TBCE mutation analysis. a Sequence traces from affected subjects. Middle Eastern subjects were homozygous for 155-166del, a Belgian subject was compound heterozygous for 66-67delAG and 1113T $\rightarrow$ A. Deleted sequences underlined above electropherograms, point mutant shown. b Two truncating mutants (Val23fsTer48, Cys371Ter) are indicated by arrows, the in-frame del52-55 is indicated by an arrowhead. CAP-Gly and leucinerich repeat domain locations are indicated. Approximate amino acid positions are below cartoon. [Taken from 54].

Fig. 2. A 14-year-old HRD patient with severe growth retardation and lack of pubertal signs.

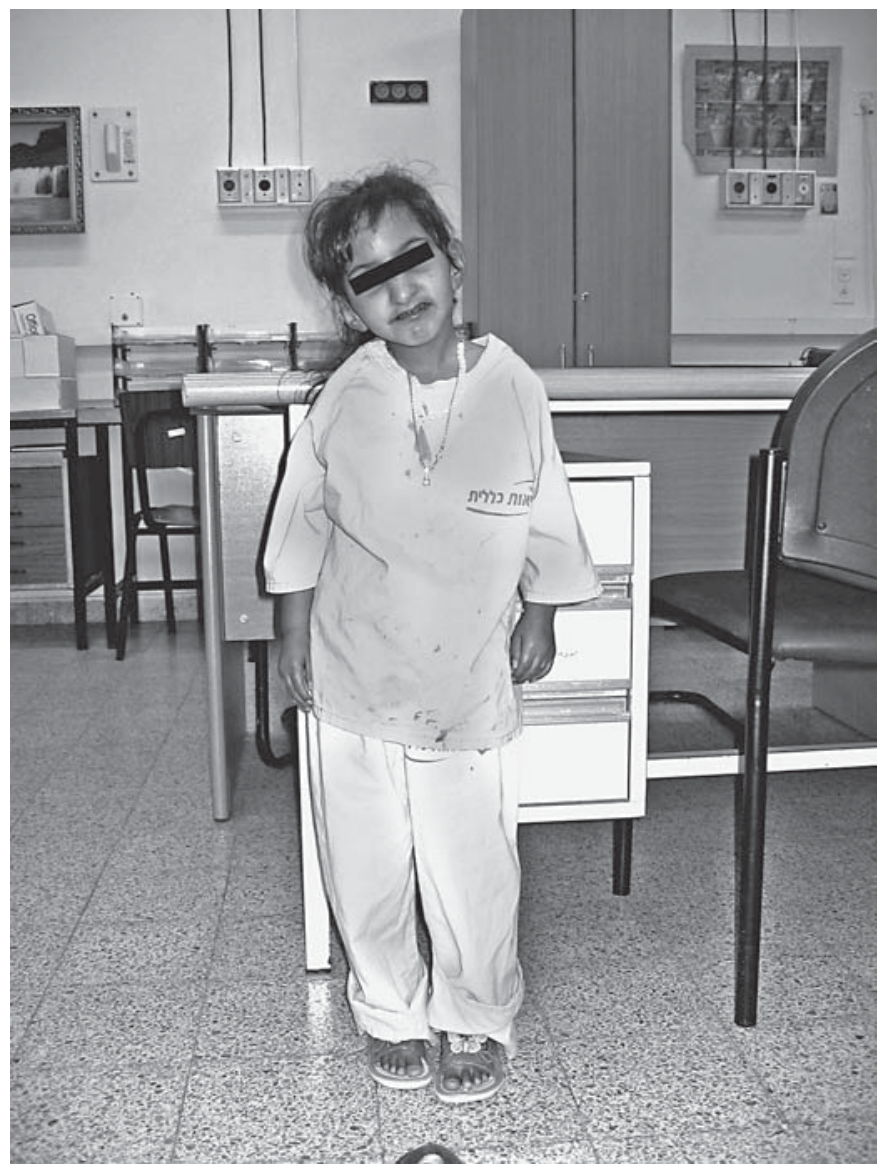


Fig. 3. Tubulin-specific chaperone folding in mammalian cells. After folding in cytoplasmic chaperonin (CCT), tubulin subunits are folded in parallel pathways that converge to produce a supercomplex that assembles native GTP-tubulin, stimulates GTP hydrolysis and then releases native GDP-tubulin. Cofactor complex-bound heterodimers can also undergo subunit exchange or sequestration of subunits.

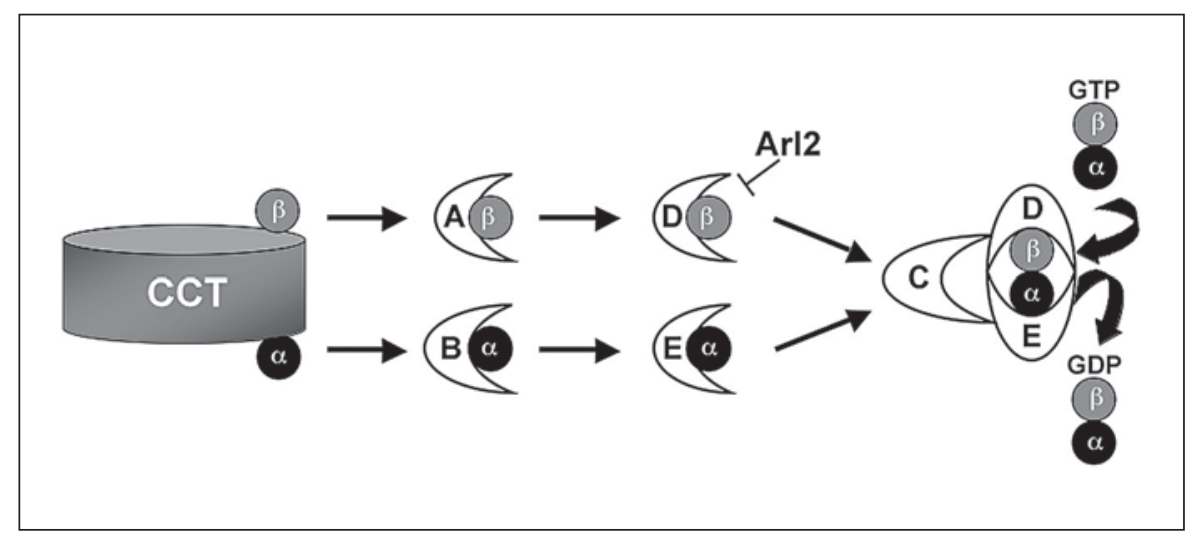

63]. In vitro folding assays suggest that in mammals $\alpha$ tubulin binds to cofactors $\mathrm{B}$ and $\mathrm{E}$, whereas $\beta$-tubulin binds to cofactors A and D. $\alpha$-Tubulin/TBCE and $\beta$-tubulin/TBCD are bound by TBCC, forming a supercomplex from which $\alpha / \beta$-tubulin heterodimers are released by GTP hydrolysis of $\beta$-tubulin. The small G-protein Arl2 appears to play a regulatory role, binding to and sequestering cofactor D [64] (fig. 3). Budding yeast mutants lacking tubulin cofactor homologs have only conditional effects and are normally not lethal [65 and references therein]. In contrast, null mutations in fission yeast TFC genes cause abnormal cell shapes and mostly result in lethality [66-70]. Genetic analysis of tubulin cofactor function in fission yeast has led to a different model of tubulin folding: an essential pathway of $\alpha$-tubulin folding involves, successively, cofactors $\mathrm{B}, \mathrm{E}$, and $\mathrm{D}$, with the Arl2 homolog acting upstream of $\mathrm{D}$, whereas a non-essential pathway of $\beta$-tubulin folding involves cofactor A passing $\beta$-tubulin on to cofactor D to associate with $\alpha$-tubulin [67-69]. Results in the plant Arabidopsis suggest that cofactors C-E and Arl2 are stringently required for microtubule formation, similar to the requirements for in vitro assays using purified mammalian cofactors [71]. PFI, the ortholog of the vertebrate Tbce in Arabidopsis, is necessary for continuous microtubule organization, mitotic division and cytokinesis but do not mediate cell cycle progression $[72,73]$. Vesicle trafficking to the division plane during cytokinesis but not to the cell surfaceduring interphase was impaired [72].

Our studies on the effect of a homozygous four amino acid deletion of TBCE(del52-55) in patients' cells demonstrated that lymphoblastoid cells showed aberrant microtubule polarity and the microtubules arrays are not centered on centrosomes in disease cells. This effect was more pronounced in fibroblasts than in keratinocytes.
Thus, the cellular phenotype may be tissue-specific despite ubiquitous transcriptional TBCE expression. Organization of the Golgi complex in patients' fibroblasts was diffuse and surrounded the nucleus, in contrast to its compact and localization near one side of the nucleus in control cells. The distribution of late endosomes which, like the Golgi complex, is microtubule-dependent, revealed an abnormally diffuse pattern in the whole cell in contrast to the predominantly perinuclear pattern observed in control cells.

Tubulin is needed for many essential life processes, including cell division and proper organelle positioning in the cell. Because chaperones are required to produce tubulin, most mutations in the genes encoding these proteins are probably lethal at a very early stage of embryogenesis. Therefore, we assume that the genetic lesions in TBCE which cause HRD syndrome in humans and progressive motor neuropathy in mouse could not totally abrogate the function of TBCE. Indeed, verification of a number of patients with phenotypes similar to HRD has not identified additional mutations in this gene [R.P. and G.D., unpubl. data].

\section{Conclusion and Future Directions in the Study of TBCE and Parathyroid Development}

The specific absence of parathyroid glands, with accompanying normal development of the thyroid and other branchial pouch derivatives, is an intriguing and unexpected aspect of a derangement in tubulin physiology. Microarray transcription analysis of TBX1 null mice did not show effect on the transcription of TBCE, or any other tubulin chaperone. However, there was a reduction to half in the transcription of the tubulin $\alpha 8$ isotype. TBCE 
transcription in the parathyroid is amongst the lowest compared to other organs [Electronic Database: GEO http://www.ncbi.nlm.nih.gov/entrez/query.fcgi? $\mathrm{CMD}=$ search $\& \mathrm{DB}=$ geo]. This may render the parathyroid particularly sensitive to compromised action caused by mutation of the TBCE. Alternatively, or in addition, the development of the parathyroid glands may require a function that is particularly sensitive to the function of the microtubule cytoskeleton, such as migration, or particular cell morphology. As an example, migration of neurons and specifically 'neurokinesis' depend upon the microtubule network [74]. It was recently demonstrated that the tubulin cytoskeleton and two microtubule-associated proteins, LIS1 and doublecortin, function with dy- nein to mediate coupling of the nucleus to the centrosome in neuronal migration [75], raising the possibility of a similar requirement for the microtubuli for the migration of the parathyroid glands. The lethality observed in TBCE mutants of fission yeasts [70] in contrast to the non-lethality of the budding yeast may demonstrate the differential requirements for the tubulin microtubule cytoskeleton. Still another possibility is that TBCE may have additional roles to its tubulin chaperone function for which the parathyroid is specifically sensitive. The interplay between the known factors involved in the parathyroid development and the TBCE and/or microtubule cytoskeleton remains to be elucidated by future studies.

\section{References}

1 Moore KL, Persaud TVN: The Developing Human: Clinically Oriented Embryology, ed 6. Philadelphia, Saunders, 1998, pp 223-225, 230.

-2 Manley NR, Capecchi MR: Hox group 3 paralogs regulate the development and migration of the thymus, thyroid, and parathyroid glands. Dev Biol 1998;195:1-15.

-3 Couly G, Creuzet S, Bennaceur S, Vincent C, le Douarin NM: Interactions between Hoxnegative cephalic neural crest cells and the foregut endoderm in patterning the facial skeleton in the vertebrate head. Development 2002;129:1061-1073.

4 Piotrowski T, Nusslein-Volhard C: The endoderm plays an important role in patterning the segmented pharyngeal region in zebrafish (Danio rerio). Dev Biol 2000;225: 339-356.

5 Thomas T, Kurihara H, Yamagishi H, Kurihara Y, Yazaki Y, Olson EN, Srivastava D: A signaling cascade involving endothelin-1, dHAND and msx 1 regulates development of neural-crest-derived branchial arch mesenchyme. Development 1998;125:3005-3014.

6 Veitch E, Begbie J, Schilling TF, Smith MM, Graham A: Pharyngeal arch patterning in the absence of neural crest. Curr Biol 1999;9: 1481-1484.

7 Wendling O, Dennefeld C, Chambon P, Mark M: Retinoid signaling is essential for patterning the endoderm of the third and fourth pharyngeal arches. Development 2000;127:1553-1562.

-8 Bockman DE, Kirby ML: Dependence of thymus development on derivatives of the neural crest. Science 1984;223:498-500.

-9 LeLievre CS, LeDouarin N: Mesenchymal derivatives of the neural crest: analysis of chimaeric quail and chick embryos. J Embryol Exp Morphol 1975;34:125-154.
10 Noden DM: The embryonic origins of avian cephalic and cervical muscles and associated connective tissues. Am J Anat 1983;168:257276.

11 Noden DM: Craniofacial development: new views on old problems. Anat Rec 1984;208: 1-13.

12 Dupe V, Ghyselinck NB, Wendling O, Chambon P, Mark M: Key roles of retinoic acid receptors $\alpha$ and $\beta$ in the patterning of the caudalhindbrain, pharyngeal arches and otocyst in the mouse. Development 1999;126:50515059.

13 Wendling O, Dennefeld C, Chambon P, Mark M: Retinoid signaling is essential for patterning the endoderm of the third and fourth pharyngeal arches. Development 2000;127:1553-1562.

14 Niederreither K, Vermot J, Le Roux I, Schuhbaur B, Chambon P, Dolle P: The regional pattern of retinoic acid synthesis by RALDH2 is essential for the development of posterior pharyngeal arches and the enteric nervous system. Development 2003;130:2525-2534.

15 Krumlauf R: Hox genes in vertebrate development. Cell 1994;78:191-201.

$\checkmark 16$ Moore-Scott BA, Manley NR: Differential expression of Sonic hedgehog along the anterior-posterior axis regulates patterning of pharyngeal pouch endoderm and pharyngeal endoderm-derived organs. Dev Biol 2005;278:323-335.

17 Wurddak H, Ittner LM, Lang KS, Leveen P, Suter U, Fischer JA, Karlsson S, Born W, Sommer L: Inactivation of TGF $\beta$ signaling in neural crest stem cells leads to multiple defects reminiscent of DiGeorge syndrome. Genes Dev 2005;19:530-535.

18 Vitelli F, Baldini A: Generating and modifying DiGeorge syndrome-like phenotypes in model organisms: is there a common genetic pathway? Trends Genet 2003;19:588-593.
19 Guris DL, Fantes J, Tara D, Druker BJ, Imamoto A: Mice lacking the homologue of the human 22q11.2 gene CRKL phenocopy neurocristopathies of DiGeorge syndrome. Nat Genet 2001;27:293-298.

20 Moon AM, Guris DL, Seo JH, Li L, Hammond J, Talbot A, Imamoto A: Crkl deficiency disrupts Fgf8 signaling in a mouse model of 22q11 deletion syndromes. Dev Cell 2006; 10:71-80.

21 Guris DL, Duester G, Papaioannou VE, Imamoto A: Dose-dependent interaction of Tbx1 and Crkl and locally aberrant RA signaling in a model of del22q11 syndrome. Dev Cell 2006;10:81-92.

22 Manley N, Capecchi MR: The role of HoxA3 in mouse thymus and thyroid development. Development 1995;121:1989-2003.

23 Kameda Y, Watari-Goshima N, Nishimaki T, Chisaka O: Disruption of the Hoxa3 homeobox gene results in anomalies of the carotid artery system and the arterial baroreceptors. Cell Tissue Res 2003;311:343-352.

-24 Kameda Y, Arai Y, Nishimaki T, Chisaka O: The role of Hoxa3 gene in parathyroid gland organogenesis of the mouse. J Histochem Cytochem 2004;52:641-651.

25 Strachan T, Read AP: PAX genes. Curr Opin Genet Dev 1994;4:427-438.

26 Stuart ET, Kioussi C, Gruss P: Mammalian Pax genes. Annu Rev Genet 1994;28:219236.

27 Neubuser A, Koseki H, Balling R: Characterization and developmental expression of Pax9, a paired-box-containing gene related to Pax1. Dev Biol 1995;170:701-716.

28 Dahl E, Koseki H, Balling R: Pax genes and organogenesis. Bioessays 1997;19:755-765. 
-29 Peters H, Neubuser A, Kratochwil K, Balling R: Pax9-deficient mice lack pharyngeal pouch derivatives and teeth and exhibit craniofacial and limb abnormalities. Genes Dev 1998;12:2735-2747.

-30 Wallin J, Eibel H, Neubuser A, Wilting J, Koseki H, Balling R: Pax1 is expressed during development of the thymus epithelium and is required for normal T-cell maturation. Development 1996;122:23-30.

-31 Su D, Ellis S, Napier A, Lee K, Manley NR: Hoxa3 and pax1 regulate epithelial cell death and proliferation during thymus and parathyroid organogenesis. Dev Biol 2001;236: 316-329.

\32 Akiyama Y, Hosoya T, Poole AM, Hotta Y: The gcm-motif: a novel DNA-binding motif conserved in Drosophila and mammals. Proc Natl Acad Sci USA 1996;93:14912-14916.

$\checkmark 33$ Kim J, Jones BW, Zock C, Chen Z, Wang H, Goodman CS, Anderson DJ: Isolation and characterization of mammalian homologs of the Drosophila gene glial cells missing. Proc Natl Acad Sci USA 1998;95:12364-12369.

-34 Gordon J, Bennett AR, Blackburn CC, Manley NR: Gcm2 and Foxn1 mark early parathyroid-and thymus-specific domains in the developing third pharyngeal pouch. Mech Dev 2001;103:141-143.

-35 Gunther T, Chen ZF, Kim J, Priemel M, Rueger JM, Amling M, Moseley JM, Martin TJ, Anderson DJ, Karsenty G: Genetic ablation of parathyroid glands reveals another source of parathyroid hormone. Nature 2000;406:199-203.

$\checkmark 36$ Ding C, Buckingham B, Levine MA: Familial isolated hypoparathyroidism caused by a mutation in the gene for the transcription factor GCMB. J Clin Invest 2001;108:12151220.

$\checkmark 37$ Kebebew E, Peng M, Wong MG, Ginzinger D, Duh QY, Clark OH: GCMB gene, a master regulator of parathyroid gland development, expression, and regulation in hyperparathyroidism. Surgery 2004;136:1261-1266.

-38 Xu PX, Adams J, Peters H, Brown MC, Heaney S, Maas R: Eyal-deficient mice lack ears and kidneys and show abnormal apoptosis of organ primordia. Nat Genet 1999;23: 113-117.

-39 Xu PX, Zheng W, Laclef C, Maire P, Maas RL, Peters $\mathrm{H}, \mathrm{Xu} \mathrm{X}$ : Eyal is required for the morphogenesis of mammalian thymus, parathyroid and thyroid. Development 2002;129: 3033-3044.

40 Peters H, Wilm B, Sakai N, Imai K, Maas R, Balling R: Pax1 and Pax9 synergistically regulate vertebral column development. Development 1999;126:5399-5408.

-41 Schepers GE, Teasdale RD, Koopman P: Twenty pairs of sox: extent, homology, and nomenclature of the mouse and human sox transcription factor gene families. Dev Cell 2002;3:167-170.
42 Bowl MR, Nesbit MA, Harding B, Levy E, Jefferson A, Volpi E, Rizzoti K, Lovell-Badge $\mathrm{R}$, Schlessinger D, Whyte MP, Thakker RV: An interstitial deletion-insertion involving chromosomes 2p25.3 and Xq27.1, near SOX3, causes X-linked recessive hypoparathyroidism. J Clin Invest 2005;115:2822-2831.

43 Lindsay EA, Botta A, Jurecic V, Carattini-Rivera S, Cheah YC, Rosenblatt HM, Bradley A, Baldini A: Congenital heart disease in mice deficient for the DiGeorge syndrome region. Nature 1999;401:379-383.

44 Lindsay EA, Vitelli F, Su H, Morishima M, Huynh T, Pramparo T, Jurecic V, Ogunrinu G, Sutherland HF, Scambler PJ, Bradley A, Baldini A: Tbx1 haploinsufficiency in the DiGeorge syndrome region causes aortic arch defects in mice. Nature 2001;410:97101.

45 Merscher S, Funke B, Epstein JA, Heyer J, Puech A, Lu MM, Xavier RJ, Demay MB, Russell RG, Factor S, Tokooya K, Jore BS, Lopez M, Pandita RK, Lia M, Carrion D, Xu H, Schorle H, Kobler JB, Scambler P, WynshawBoris A, Skoultchi AI, Morrow BE, Kucherlapati R: TBX1 is responsible for cardiovascular defects in velo-cardio-facial/DiGeorge syndrome. Cell 2001;104:619-629.

46 Vitelli F, Morishima M, Taddei I, Lindsay EA, Baldini A: Tbx1 mutation causes multiple cardiovascular defects and disrupts neural crest and cranial nerve migratory pathways. Hum Mol Genet 2002;11:915-922.

47 Ivins S, Lammerts van Beuren K, Roberts C James C, Lindsay E, Baldini A, Ataliotis P, Scambler PJ: Microarray analysis detects differentially expressed genes in the pharyngeal region of mice lacking Tbx1. Dev Biol 2005;285:554-569.

48 Van Esch H, Groenen P, Nesbit MA, Schuffenhauer S, Lichtner P, Vanderlinden G, Harding B, Beetz R, Bilous RW, Holdaway I, Shaw NJ, Fryns JP, Van de Ven W, Thakker RV, Devriendt K: GATA3 haplo-insufficiency causes human HDR syndrome. Nature 2000;406:419-422.

49 Pandolfi PP, Roth ME, Karis A, Leonard MW, Dzierzak E, Grosveld FG, Engel JD, Lindenbaum MH: Targeted disruption of the GATA3 gene causes severe abnormalities in the nervous system and in fetal liver haematopoiesis. Nat Genet 1995;11:40-44.

50 Nesbit MA, Bowl MR, Harding B, Ali A, Ayala A, Crowe C, Dobbie A, Hampson G, Holdaway I, Levine MA, McWilliams R, Rigden S, Sampson J, Williams AJ, Thakker RV: Characterization of GATA3 mutations in the hypoparathyroidism, deafness, and renal dysplasia (HDR) syndrome. J Biol Chem 2004;279:22624-22634.

51 Tahseen K, Khan S, Uma R, Usha R, Al Ghanem MM, Al Awadi SA, Farag TI: KennyCaffey syndrome in six Bedouin sibships: autosomal recessive inheritance is confirmed. Am J Med Genet 1997;69:126-132.
52 Hershkovitz E, Shalitin S, Levy J, Leiberman E, Weinshtock A, Varsano I, Gorodischer R: The new syndrome of congenital hypoparathyroidism associated with dysmorphism, growth retardation, and developmental delay - a report of six patients. Isr J Med Sci 1995;31:293-297.

53 Sanjad SA, Sakati NA, Abu-Osba YK, Kaddoura R, Milner RD: A new syndrome of congenital hypoparathyroidism, severe growth failure, and dysmorphic features. Arch Dis Child 1991;66:193-196.

54 Parvari R, Hershkovitz E, Grossman N, Gorodischer R, Loeys B, Zecic A, Mortier G, Gregory S, Sharony R, Kambouris M, Sakati N, Meyer BF, Al Aqeel AI, Al Humaidan AK, Al Zanhrani F, Al Swaid A, Al Othman J, Diaz GA, Weiner R, Khan KT, Gordon R, Gelb BD; HRD/Autosomal Recessive Kenny-Caffey Syndrome Consortium: mutation of TBCE causes hypoparathyroidism-retardation-dysmorphism and autosomal recessive Kenny-Caffey syndrome. Nat Genet 2002;32:448-452.

55 Hershkovitz E, Parvari R, Diaz GA, Gorodischer R: Hypoparathyroidism-retardation-dysmorphism (HRD) syndrome - a review. J Pediatr Endocrinol Metab 2004;17: 1583-1590.

56 Boynton JR, Pheasant TR, Johnson BL, Levin DB, Streeten BW: Ocular findings in Kenny's syndrome. Arch Ophthalmol 1979;97:896900.

57 Bommel H, Xie G, Rossoll W, Wiese S, Jablonka S, Boehm T, Sendtner M: Missense mutation in the tubulin-specific chaperone $\mathrm{E}$ (Tbce) gene in the mouse mutant progressive motor neuronopathy, a model of human motoneuron disease. J Cell Biol 2002;159: 563-569.

58 Martin N, Jaubert J, Gounon P, Salido E, Haase G, Szatanik M, Guenet JL: A missense mutation in Tbce causes progressive motor neuronopathy in mice. Nat Genet 2002;32: 443-447.

59 Schmalbruch H, Jensen HJ, Bjaerg M, Kamieniecka Z, Kurland L: A new mouse mutant with progressive motor neuronopathy. J Neuropathol Exp Neurol 1991;50:192-204.

60 Nogales E: Structural insight into microtubule function. Annu Rev Biochem 2000;69: 277-302.

61 Leroux MR, Hartl FU: Protein folding: versatility of the cytosolic chaperonin TRiC/ CCT. Curr Biol 2000;10:R260-264.

62 Tian G, Huang Y, Rommelaere H, Vandekerckhove J, Ampe C, Cowan NJ: Pathway leading to correctly folded $\beta$-tubulin. Cell 1996;86:287-296.

63 Tian G, Lewis SA, Feierbach B, Stearns T, Rommelaere H, Ampe C, Cowan NJ: Tubulin subunits exist in an activated conformational state generated and maintained by protein cofactors. J Cell Biol 1997;138:821832. 
64 Bhamidipati A, Lewis SA, Cowan NJ: ADP ribosylation factor-like protein $2(\mathrm{Arl} 2) \mathrm{reg}-$ ulates the interaction of tubulin-folding cofactor D with native tubulin. J Cell Biol 2000; 149:1087-1096.

-65 Fleming JA, Vega LR, Solomon F: Function of tubulin binding proteins in vivo. Genetics 2000;156:69-80.

-66 Radcliffe PA, Toda T: Characterisation of fission yeast alp11 mutants defines three functional domains within tubulin-folding cofactor B. Mol Gen Genet 2000;263:752-760.

-67 Radcliffe PA, Garcia MA, Toda T: The cofactor-dependent pathways for $\alpha$ - and $\beta$-tubulins in microtubule biogenesis are functionally different in fission yeast. Genetics 2000; 156:93-103.

68 Radcliffe PA, Vardy L, Toda T: A conserved small GTP-binding protein Alp41 is essential for the cofactor-dependent biogenesis of microtubules in fission yeast. FEBS Lett 2000;468:84-88.
69 Radcliffe PA, Hirata D, Vardy L, Toda T: Functional dissection and hierarchy of tubulin-folding cofactor homologues in fission yeast. Mol Biol Cell 1999;10:2987-3001.

70 Grishchuk EL, McIntosh JR: Stolp, a fission yeast protein similar to tubulin folding $\mathrm{CO}_{-}$ factor E, plays an essential role in mitotic microtubule assembly. J Cell Sci 1999;112: 1979-1988.

71 Tian G, Bhamidipati A, Cowan NJ, Lewis SA: Tubulin folding cofactors as GTPase-activating proteins. GTP hydrolysis and the assembly of the $\alpha / \beta$-tubulin heterodimer. J Biol Chem 1999;274:24054-24058.
72 Steinborn K, Maulbetsch C, Priester B, Trautmann S, Pacher T, Geiges B, Küttner F, Lepiniec L, Stierhof YD, Schwarz H, et al: The Arabidopsis PILZ group genes encode tubulin-folding cofactor orthologs required for cell division but not cell growth. Genes Dev 2002;16:959-971.

$>73$ Mayer U, Herzog U, Berger F, Inze D, Jurgens $\mathrm{G}$ : Mutations in the pilz group genes disrupt the microtubule cytoskeleton and uncouple cell cycle progression from cell division in Arabidopsis embryo and endosperm. Eur J Cell Biol 1999;78:100-108.

74 Samuels BA, Tsai LH: Nucleokinesis illuminated. Nat Neurosci 2004;7:1169-1170.

-75 Tanaka T, Serneo FF, Higgins C, Gambello MJ, Wynshaw-Boris A, Gleeson JG: Lis1 and doublecortin function with dynein to mediate coupling of the nucleus to the centrosome in neuronal migration. J Cell Biol 2004;165: 709-721. 